\title{
PERSEPSI MASYARAKAT TERHADAP DAMPAK INDUSTRI SEMEN DI WILAYAH KABUPATEN BOOLANG, MONGONDOW, SULAWESI UTARA
}

\author{
Ilham Akbar Mustafa1, Hayati Sari Hasibuan², Ahyahudin Sodri ${ }^{3}$ \\ 1,2,3 Sekolah Ilmu Lingkungan, Universitas Indonesia \\ Email: m.ilhamakbar17@gmail.com
}

\begin{abstract}
ABSTRAK
Industri semen adalah salah satu bidang industri besar yang ada di berbagai wilayah di Indonesia yang memberikan dampak positif maupun dampak negatif untuk kelestarian lingkungan serta masyarakat yang berada disekitarnya. Industri yang berupa prodak suatu barang atau jasa dari suatu pemanfaatan dan pengolahan sumber daya alam menghasilkan berbagai dampak di berbagai aspek yaitu aspek ekonomi, aspek lingkungan, dan aspek sosial. Tujuan dari penelitian ini adalah menganalisis persepsi masyarakat akibat adanya kegiatan industri semen di wilayah strategis baru yaitu wilayah Boolang, Mongondow, Sulawesi Utara. Metode yang digunakan dalam penelitian ini adalah kualitatif menggunakan analisis deskriptif dan tabulasi. Hasil penelitian menunjukan bahwa mayoritas masyarakat belum merasakan adanya perubahan dampak berarti dari adanya industri semen. Kesimpulan penelitian ini adalah belum adanya dampak positif berarti dari adanya industri semen di wilayah Kabupaten Boolang, Mongondiw, Sulawesi Utara.
\end{abstract}

Kata kunci: Industri semen, dampak ekonomi, dampak sosial, persepsi masyarakat 


\section{IJEEM: Indonesian Journal of Environmental Education and Management e-ISSN: 2549-5798 \\ Vol.6 No. 2, 31 Juli 2021 \\ DOI : doi.org/10.21009/IJEEM.062.07}

\section{PENDAHULUAN}

Perkembangan industri saat ini adalah suatu tanda bahwa adanya usaha manusia dalam menyediakan kebutuhan dan adanya peningkatan permintaan untuk memenuhi kebutuhan barang dan jasa. Hal ini juga ditandai dengan dibangunnya berbagai kawasan industri di wilayah Indonesia sebagai usaha untuk pemerataan ekonomi di seluruh wilayah Indonesia. Pemahaman ini juga selaras dengan laporan komisi dunia tentang lingkungan dan pembangunan yang berjudul Our Common Future yaitu populasi yang berkembang pesat akan dapat menyebabkan peningkatan tekanan pada sumber daya dan memperlambat setiap kenaikan standar hidup; dengan demikian pembangunan berkelanjutan hanya dapat ditempuh jika ukuran populasi dan pertumbuhan selaras dengan potensi produktif perubahan ekosistem (United Nations, 1987). Industri adalah seluruh bentuk kegiatan ekonomi yang mengolah bahan baku dan/atau memanfaatkan sumber daya alam sehingga menghasilkan barang dan/atau jasa yang mempunyai nilai tambah ekonomi dan manfaat yang lebih tinggi (Rizal, 2013).

Kegiatan industri di suatu wilayah menjadi suatu aktivitas penting yang melibatkan tidak hanya pelaku industri yaitu perusahaan namun juga pemerintah setempat dan masyarakat sekitar. Industri yang berupa prodak suatu barang atau jasa dari suatu pemanfaatan dan pengolahan sumber daya alam menghasilkan berbagai dampak di berbagai aspek yaitu aspek ekonomi, aspek lingkungan, dan aspek sosial. Hal ini sesuai dengan konsep pembangunan berkelanjutan dalam bidang industri yang mencakup aspek lingkungan, aspek sosial, dan aspek ekonomi. Aspek nyata yang dapat secara langsung terlihat adalah dampak positif pada aspek ekonomi yaitu adanya peningkatan pendapatan atau kenaikan perekonomian di wilayah industri tersebut didirikan. Namun, perkembangan berbagai industri juga memberikan dampak negatif di beberapa aspek kehidupan manusia. Aspek lingkungan adalah aspek yang paling dominan terdampak dari suatu kegiatan eksploitasi sumber daya alam. Hal ini karena persoalan yang kompleks serta dampak jangka panjang atau long term effect yang ditimbulkan dari suatu kegiatan terhadap lingkungan tidak terlihat dan dirasa secara langsung namun sedikit demi sedikit dalam suatu waktu tertentu. Secara global dampak negatif yang mungkin timbul akibat adanya pembangunan industri semen, menurut Gusano et al., (2014); Madugu (2008); Surahyo (2019); Githiria dan 
Onifade (2020); El-Haggar dan Samaha (2019), antara lain adalah penurunan kualitas lingkungan seperti deforestasi yang menyebabkan gangguan tanah dan erosi serta berubah dan hilangnya habitat untuk fauna dan flora asli sedangkan menurut Yan et al., (2009) dampak positif yang dapat dirasakan setelah adanya pembangunan industri semen yang berkelanjutan antara lain adalah membantu pembangunan berkelanjutan untuk masyarakat lokal, yaitu dengan membuka peluang kerja baru bagi penduduk setempat yang terdampak dan meningkatkan pendapatan penduduk lokal, sehingga terjadi siklus mutualisme satu sama lainnya yaitu keamanan sosial dan lingkungannya.

Selain kedua aspek tersebut, aspek sosial adalah aspek terkompleks yang timbul karena permasalahan sosial dan dapat timbul pada pra pembangunan hingga industri beroperasi. Berbagai permasalahan sosial akibat dampak permasalahan lingkungan dan ekonomi menjadi fokus penelitian ini. Salah satu hubungan antara penurunan kualitas lingkungan hidup dan manusia (sosial) yaitu sebagian besar penurunan kualitas lingkungan hidup hasil dari tindakan atau perilaku manusia dan berdampak kepada kelangsungan hidup manusia (Barry, 2007). Permasalahan sosial seperti konflik sosial, ketidak merataan sosial, dan lainnya dapat diketahui dari berbagai sumber seperti observasi dan persepsi masyarakat. Persepsi secara umum merupakan proses perolehan, penafsiran, pemilihan dan pengaturan informasi indrawi. Persepsi berlangsung pada saat seseorang meniram stimulus dari dunia luar yang ditangkap oleh organ-organ bantunya yang kemudian masuk ke dalam otak. Persepsi merupakan proses pencarian informasi untuk dipahami yang menggunakan alat pengindraan (Sarwono, 2010).

Industri semen adalah salah satu bidang industri besar yang ada di berbagai wilayah di Indonesia. Industri semen nasional adalah industri strategis yang banyak dibutuhkan sebagai industri pendukung utama untuk pembangunan infrastruktur seperti jembatan, pelabuhan, bangunan dan lainnya (Putri et al., 2013). Peningkatan kebutuhan dan konsumsi domestik semen di Indonesia memberikan peluang bagi perusahaan nasional maupun perusahaan asing untuk membangun industri semen di Indonesia. Berbagai industri semen asing saat ini telah memasuki wilayah Indonesia dengan membuat pabrik semen langsung di berbagai wilayah. Negara maju seperti Cina telah membangun beberapa pabrik semen di Indonesia untuk mengembangkan bisnis produsen semen di wilayah Indonesia seperti seperti Manokwari Papua Barat, Maros Sulawesi Selatan, Merak Banten dan Tanjung 
Tabalong Kalimantan Selatan dan yang terbaru di Kabupaten Bolaang, Mongondow Sulawesi Utara. Wilayah Kabupaten Bolaang, Mongondow Sulawesi Utara adalah wilayah yang dekat dengan pelabuhan sehingga menjadi kawasan strategis untuk mendukung pergerakan mobilisasi dan transportasi hasil industri semen ke dalam dan luar negeri.

Tujuan dari penelitian ini adalah menganalisis persepsi masyarakat akibat adanya kegiatan industri semen di wilayah strategis baru yaitu wilayah Boolang, Mongondow, Sulawesi Utara. Analisis ini juga didukung dengan analisis berbagai pendapat para pemangku kebijakan tentang lokasi dan perubahan yang ada sebagai dampak adanya kegiatan industri semen di wilayah tersebut.

\section{METODOLOGI PENELITIAN}

Penelitian ini berlokasi di daerah kawasan industri semen milik asing yang ada di Kabupaten Boolang, Mongondow, Sulawesi Utara. Pendekatan yang digunakan dalam penelitian ini adalah kualitatif dengan metode kuantitaif dan kualitatif dengan observasi lapangan, interview, studi literature, dan kuesioner. Populasi dan sampel penelitian ini yaitu masyarakat. Populasi masyarakat pada penelitian ini adalah seluruh masyarakat yang bermukim di Desa Solog Kecamatan Lolak, Kabupaten Bolaang Mongondow, Provinsi Sulawesi Utara. Jumlah populasi masyarakat desa Solog adalah sebesar 378 Kepala Keluarga (KK). Penentuan jumlah sampel dilakukan dengan rumus Slovin dengan derajat kesalahan $10 \%$.

$n=\frac{N}{1+N e^{2}}$

Keterangan:

$\mathrm{n}=$ besaran sampel

$\mathrm{N}=$ besaran populasi

$\mathrm{e}=$ nilai kritis (batas ketelitian) yang diinginkan (persen kelonggaran ketidaktelitian karena kesalahan penarikan sampel)

Berdasarkan kriteria tersebut, maka jumlah sampel responden yang didapat adalah $79 \mathrm{KK}$. Jumlah sampel tersebut akan ditambahkan 5\% dari jumlah sampel untuk mengantisipasi apabila terdapat data yang tidak baik dalam riset, sehingga total jumlah sampel pada riset ini sebesar $83 \mathrm{KK}$. Metode pengambilan sampel untuk $83 \mathrm{KK}$ tersebut akan diambil dengan 
menggunakan teknik simple random sampling. Selanjutnya, data dianalisis dengan deskriptif, tabulasi, serta rata-rata dari jumlah jawaban yang ada.

\section{HASIL DAN PEMBAHASAN}

Luas wilayah dari Desa Solog, Kabupaten Boolang adalah 23,41 $\mathrm{Km}^{2}$ dan merupakan desa terluas kedua di Kecamatan Lolak, Kabupaten Boolang Mongondow. Lokasi industri semen sendiri berada sekitar $2 \mathrm{~km}$ dari dermaga yaitu bagian utara dari Desa Solog. Berdasarkan data yang diperoleh, sektor pertambangan dan penggalian adalah salah satu sektor yang menyumbang penghasilan daerah di Kabupaten Boolang Mongondow. Industri pertambangan dan penggalian di Kabupaten Boolang Mongondow menyumbang 7,93\% distribusi PDRB di tahun 2019. Gambar 1 adalah Distribusi PDRB Sektor Pertambangan dan Penggalian Kabupaten Boolang Mongondow 2015-2019. Pertumbuhan ekonomi di Kabupaten Boolang Mongondow tahun 2018 mencapai 7,5\% dan ditahun 2019 mengalami peningkatan menjadi $7,84 \%$.

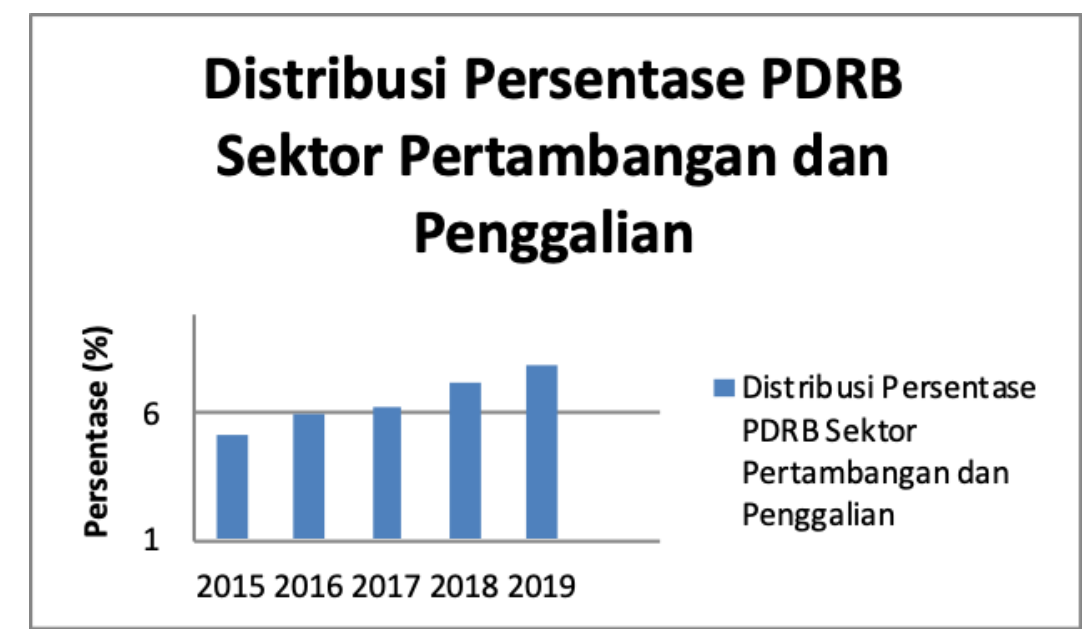

\section{Gambar 1 Distribusi Persentase PDRB Sektor Pertambangan dan Penggalian Kabupaten Boolang Mongondow (BPS Kab.BoolangMongondow, 2020)}

Berdasarkan data yang telah diperoleh, salah satu faktor yang menyumbang persentase adalah sektor pertambangan dan penggalian. Adanya peningkatan signifikan pada tahun 2017 hingga 2019 di sektor pertambangan dan penggalian. Sektor pertambangan dan penggalian mengalami pertumbuhan tertinggi dibanding sektor lain yaitu sebesar $14,4 \%$ 
pada tahun 2019. Produksi semen mulai dijalankan pada tahun 2017 sehingga dampak terhadap ekonomi wilayah Kabupaten Boolang Mongondow mengalami peningkatan hingga saat ini hampir 3 tahun beroperasi.

Tabel 1. Jenis Kelamin

\begin{tabular}{|l|c|c|}
\hline \multicolumn{1}{|c|}{ Indikator } & Jumlah Responden (KK) & Presentase \\
\hline Wanita & 18 & $22 \%$ \\
\hline Pria & 65 & $78 \%$ \\
\hline Jumlah & $\mathbf{8 3}$ & $\mathbf{1 0 0 \%}$ \\
\hline
\end{tabular}

Hasil survey menunjukkan bahwa dari ke 83 responden, sebanyak 22\% adalah wanita, sedangkan sisanya sebanyak 78 persen adalah pria.

Tabel 2. Usia

\begin{tabular}{|l|c|c|}
\hline \multicolumn{1}{|c|}{ Indikator } & Jumlah Responden (KK) & Presentase \\
\hline$\leq 24$ Tahun & 3 & $4 \%$ \\
\hline 25-40 Tahun & 6 & $7 \%$ \\
\hline 41-64 Tahun & 40 & $48 \%$ \\
\hline$\geq 65$ Tahun & 34 & $41 \%$ \\
\hline Jumlah & $\mathbf{8 3}$ & $\mathbf{1 0 0 \%}$ \\
\hline
\end{tabular}

Usia adalah salah satu faktor yang mempengaruhi seseorang secara fisik, psikis dan sosial dalam pembentukan perilakunya. Usia dapat menunjukkan kemampuan seseorang untuk melakukan tindakan berdasarkan pengalaman dan pengetahuan yang dimiliki. Selain itu usia adalah faktor yang mempengaruhi kematangan seseorang dalam melaksanakan fungsi dan tugas serta peranan sosialnya dalam kehidupan baik di lingkungan keluarga dan masyarakat.

Berdasarkan hasil survey, mayoritas kepala keluarga masyarakat telah memasuki usia lansia yaitu sebanyak $34 \mathrm{KK}$ atau sekitar $41 \%$ dengan usia di atas 65 tahun sedangkan lansia awal sebanyak $40 \mathrm{KK}$ atau sekitar 48\% dengan usia 41-64 tahun. Sisanya minoritas berusia 25-40 tahun sebanyak $6 \mathrm{KK}$ atau sekitar 7\%, sedangkan usia dibawah 24 tahun sebanyak 3 KK atau sekitar 4\%. Kondisi ini tentunya mempunyai suatu gambaran bahwa masyarakat memiliki pengetahuan atau wawasan serta pengalaman yang matang untuk menyampaikan aspirasinya mengenai dampak lingkungan yag terjadi disekitarnya. 
Tabel 3. Pekerjaan Masyarakat

\begin{tabular}{|l|c|c|}
\hline \multicolumn{1}{|c|}{ Indikator } & Jumlah Responden (KK) & Presentase \\
\hline Petani & 34 & $41 \%$ \\
\hline Nelayan & 25 & $30 \%$ \\
\hline Karyawan PT. Conch & 3 & $4 \%$ \\
\hline Perangkat desa \& PNS & 8 & $10 \%$ \\
\hline Jasa/Pedagang & 5 & $6 \%$ \\
\hline Pengangguran/serabutan & 8 & $10 \%$ \\
\hline Jumlah & $\mathbf{8 3}$ & $\mathbf{1 0 0 \%}$ \\
\hline
\end{tabular}

Pekerjaan atau mata pencaharian masyarakat dibagi menjadi 6 kategori diantaranya petani, nelayan, karyawan Industri semen, perangkat desa atau PNS, Jasa atau pedagang, serta pengangguran atau serabutan. Petani dan nelayan adalah pekerjaan yang didominasi oleh masyarakat sebanyak $71 \%$, yaitu terdiri atas $34 \mathrm{KK}$ petani atau sekitar $41 \%$ dan sebanyak $25 \mathrm{KK}$ nelayan atau sekitar $30 \%$. Sisanya bermata pencaharian sebagai Karyawan Industri semen sebayak $3 \mathrm{KK}$ atau sekitar $4 \%$, bemata pencaharian sebagai perangkat desa atau PNS sebanyak $8 \mathrm{KK}$ atau sekitar 10\%, bermata pencaharian sebagai jasa atau pedagang sebanyak $5 \mathrm{KK}$ atau sekitar $6 \%$, dan yang terakhir bermata pencaharian sebagai pengangguran atau serabutan sebanyak $8 \mathrm{KK}$ atau sekitar $10 \%$. Berdasarkan kuesioner tersebut, $2 \mathrm{KK}$ yang saat ini bermata pencaharian sebagai nelayan, mengaku pernah menjadi karyawan di Industri semen, mereka mengundurkan diri dari Industri semen dikarenakan upah yang tidak sesuai dan jam kerja yang melebihi standar jam kerja yaitu 12 jam.

Pada persepsi masyarakat, terdapat beberapa pertanyaan yang diajukan sebagai kuesioner ke sampel masyarakat. Kuesioner tersebut meliputi i indikator sosial terkait pengetahuan masyarakat mengenai sosial ekonomi yaitu: 
Tabel 4. Indikator persepsi masyarakat terhadap dampak industri semen

Persepsi masyarakat terhadap dampak Indikator sosial ekonomi

industri semen

1. Adanya perubahan pekerjaan/mata pencaharian penduduk setelah adanya pembangunan Industri semen.

2. Terdapat lahan pabrik Industri semen yang belum dipergunakan boleh dipakai untuk lahan pertanian penduduk.

3. Pembangunan Industri semen membawa pengaruh kehidupan seperti tambahan pendapatan penduduk.

4. Adanyaperubahan tingkat pendidikan setelah adanya pembangunan Industri semen.

Sebagian besar masyarakat atau sebanyak $72 \mathrm{KK}$ atau sekitar $87 \%$ responden berpendapat bahwa Industri sementidak memberikan konstribusi perubahan pekerjaan/mata pencaharian, sedangkan sisanya sebanyak 11 KK menyatakan bahwa Industri semenmemberikan perubahan pekerjaan/mata pencaharian. Berdasarkan ke $11 \mathrm{KK}$ tersebut, hanya ada $3 \mathrm{KK}$ diantaranya yang menyatakan perubahan pekerjaan/mata pencaharian dari petani menjadi karyawan industri semen, sedangkan sisanya perubahan pekerjaan/mata pencaharian tidak bersangkutan dengan Industri semenseperti dari petani menjadi perangkat desa, dari petani menjadi buruh harian lepas, dari nelayan menjadi kuli bangunan, dan dari petani menjadi nelayan.

Pada indikator penggunaan lahan oleh penduduk, sebagian besar masyarakat atau sebanyak $75 \mathrm{KK}$ menjawab Industri sementidak mengizinkan penduduk menggunakan lahan untuk bertani, sedangkan ke $8 \mathrm{KK}$ lainnya menjawab diperbolehkan menggunakan lahan Industri semenuntuk aktivitas pertanian penduduk. Berdasarkan alasan masyarakat ( $83 \mathrm{KK}$ ) yang didapat pada saat wawancara lapangan mereka menjawab bahwa tidak diperbolehkannya masyarakat menggunakan lahan untuk bertani dikarenakan masyarakat menganggap: "lokasi Industri semensudah diberikan pagar sekelilingnya sehingga 
masyarakat tidak bisa memasukinya", "memasuki areanya saja tidak bisa apalagi untuk bertani", "kami sudah tidak mempunyai hak lahan disitu", "kami tidak diizinkan menggunakan lahan untuk pertanian karena menganggu aktifitas karyawan", dan lain sebagainya. Disisi lain terdapat pengecualian pada jawaban masyarakat yang menjawab ya, dimana masyarakat menjawab Industri semenmemperbolehkan masyarakat untuk menggunakan lahannya untuk aktivitas pertanian, namun tetap menggunakan sistem sewa atau penggarap harus memberikan jasa tanahnya.

Selanjutnya, pada Mayoritas masyarakat sebanyak 75 KK atau sekitar 90\% mengatakan tidak ada pengaruh tambahan pendapatan, sedangkan $8 \mathrm{KK}$ lainnya atau sekitar $10 \%$ mengatakan ada. Berdasarkan jawaban dari masyarakat yang menjawab ya, memiliki alasan bahwa penghasilan mereka memang berubah namun bukan bertambah tetapi menjadi berkurang. Hal ini dapat terlihat dari semakin sulitnya atau tidak adanya lagi lahan dan hutan untuk ditanami, sehingga para petani sulit untuk mencukupi kehidupan sehari-hari, sedangkan untuk nelayan semenjak dibangunnya pelabuhan di wilayah industri semen, maka nelayan kehilangan tempat mencari ikan karena nelayan tidak diperbolehkan memancing di area pelabuhan tersebut, dan aktivitas nelayan juga mengalami kesulitan akibat beroperasi kapal. Para nelayan juga mengaku bahwa hasil tangkapan mereka menurun dikarenakan adanya pencemaran air laut akibat tumpahan-tumpahan minyak dari kapal pengangkut semen, serta pengotoran air laut lainnya seperti abu semen dan batu bara. Masyarakat juga menyadari bahwa pencemaran yang berasal dari kapal-kapal tersebut mengganggu aktivitas pertumbuhan hutan mangrove tempat habitat ikan-ikan.

Pada indikator tingkat pendidikan, sebanyak $79 \mathrm{KK}$ atau setara dengan $95 \%$ masyarakat menjawab tidak ada perubahan tingkat pendidikan setelah adanya pembangunan industri semen, sedangkan sisanya sebanyak $4 \mathrm{KK}$ atau setara dengan 5\% masyarakat menyatakan ya ada perubahan tingkat pendidikan setelah adanya pembangunan industri semen. Masyarakat yang menjawab ya, beralasan bahwa perubahan tingkat pendidikan yang mereka miliki bukan dikarenakan dari Industri semenitu sendiri, namun karena merekalah yang berusaha melanjutkan pendidikan ke tingkat yang lebih tinggi.

Berdasarkan analisis yang dilakukan pada persepsi masyarakat, keberadaan industri semen di wilayah Kabupaten Boolang Mongondow, Sulawesi Utara belum memberikan dampak positif yang terasa bagi masyarakat sekitar. Meskipun industri semen dapat 
meningkatkan ekonomi di PDRB dan secara nasional, namun kontribusi pada masyarakat di wilayah tersebut belum secara nyata terlihat memberikan dampak positif di bidang ekonomi maupun sosial, lingkungan.

\section{KESIMPULAN}

Berdasarkan hasil penelitian yang dilakukan, dapat diketahui bahwa dari persepsi masyarakat yang ada mengenai dampak industri semen di Kabupaten Boolang, Mongondow, Sulawesi Utara belum memberikan dampak positif yang signifikan yang dirasakan oleh masyarakat setempat. Kerja sama antara perusahaan dan pemerintah serta peran serta masyarakat diperlukan untuk memunculkan dampak positif dari adanya industri semen di wilayah tersebut.

\section{DAFTAR PUSTAKA}

Barry, J. (2007). Environment and Social Theory. London: Routledge.

Diego Garc'ia-Gusano; Israel Herrera; Daniel Garra in; Yolanda Lecho'n; Helena Cabal. (2014). Life cycle assessment of the Spanish cement industry: implementation of environmental-friendly solutions. Clean Techn Environ Policy DOI 10.1007/s10098014-0757-0.

El-Haggar, S. and Samaha. A. (2019). Sustainable Industrial Community. Roadmap for Global Sustainability - Rise of the Green Communities, Advances in Science, Technology \& Innovation. https://doi.org/10.1007/978-3-030-14584-2_9. Springer Nature Switzerland AG 2019.

Githiria, Joseph Muchiri. dan Onifade, Moshood. (2020). The impact of mining on sustainable practices and the traditional culture of developing countries. AESS 2020. Journal of Environmental Studies and Sciences. https://doi.org/10.1007/s13412-020-00613-w

Madugu. G. Kabir A. I. (2008). Assessment of environmental impact on air quality by cement industry and mitigating measures: a case study. Springer Science + Business Media B

Putri, F.A., Hildayati A., Laila S. (2013). Review Industri Semen. Universitas Negeri Padang 
IJEEM: Indonesian Journal of Environmental Education and Management e-ISSN: 2549-5798

Vol.6 No. 2, 31 Juli 2021

DOI : doi.org/10.21009/IJEEM.062.07

Rizal, Reda. (2013). Manajemen Ekologi Industri. Penerbit Universitas Indonesia (UI-Press), 2013. ISBN: 978-979-456-533-9.

Sarwono, Sarlito W. (2010). Pengantar Psikologi Umum. Jakarta: Rajawali Pers

Surahyo, A. (2019). Sustainable Concrete. Concrete Construction, Springer Nature Switzerland AG 2019. https://doi.org/10.1007/978-3-030-10510-5_5

United Nations. (1987). Report of the World Commission on Environment and Development Our Common Future. Oslo: Gro Harlem Brundland

Yan, Qishe; Zhou, Chang-Bo; Peng Qu; Rui-qin Zhang. (2009). The promotion of clean development mechanism to cement industry capturing waste heat for power generation in China. Mitig Adapt Strateg Glob Change (2009) 14:793-804. DOI 10.1007/s11027-009-9199-0 